\title{
Can host reaction animal models be used to predict and modulate skin regeneration?
}

\author{
T. C. Santos, R. L. Reis and A. P. Marques* \\ 3Bs Research Group - Biomaterials, Biodegradables and Biomimetics, University of Minho, Taipas, and ICVS-3Bs - PT Government \\ Associate Laboratory, Braga/Guimarães, Portugal
}

\begin{abstract}
The study of host reactions in the biomedical and tissue engineering (TE) fields is a key issue but somehow set aside where TE constructs are concerned. Every day new biomaterials and TE constructs are being developed and presented to the scientific community. The combination of cells and biomolecules with scaffolding materials, as TE constructs, make the isolation and the understanding of the effect of each one those elements over the overall host reaction difficult. Eventually, all variables influence the host reaction and the performance of the constructs. For this reason, current assessment of the in vivo performance of TE constructs follows individual approaches, using specific animal models to independently provide insights regarding the contribution of the biomaterials/scaffolds towards the host reaction, and of all the constructs regarding their functionality. Skin wound healing progress into tissue regeneration or repair is highly dependent on the specificities of the inflammatory stage, as demonstrated by comparison between fetal and adult mechanisms. Thus, it would be expected that insights acquired from host tissue reaction evaluation to biomaterials/scaffolds would be explored to predict healing progression and improve the functionality of skin TE constructs. The rational of this review is to make a comprehensive analysis of to what extent the knowledge obtained from the evaluation of in vivo host reactions to implantable biomaterials/scaffolds has been used in the design of skin TE strategies, by promoting tissue regeneration rather than repair. Copyright (C) 2016 John Wiley \& Sons, Ltd.
\end{abstract}

Received 17 July 2014; Revised 3 November 2015; Accepted 2 December 2015

Keywords host reaction; animal models; biomaterials; scaffolds; tissue engineering; skin tissue engineering; inflammation; immune reaction; skin regeneration

\section{Introduction}

The main objective of skin wound closure is to re-establish tissue and organ homeostasis preventing the invasion of microorganisms and infections. It is obvious that the sooner the wound heals, the lower is the infection probability and the faster the organism may return to its 'normal' function. However, accelerated closure is mainly achieved by rapid interposition of fibroblasts that will form the scar tissue.

\footnotetext{
*Correspondence to: A. P. Marques, 3Bs Research Group Biomaterials, Biodegradables and Biomimetics, University of Minho, Headquarters of the European Institute of Excellence on Tissue Engineering and Regenerative Medicine, AvePark, 4806909 Taipas, Guimarães, Portugal. E-mail: apmarques75@gmail. com
}

Many text books (Fantone and Ward, 1999; Frank and Kaempfer, 2003; Gamelli and He, 2003; Williams, 2001) and review papers (Gurtner et al., 2008; Martin et al., 2003; Martin and Leibovich, 2005; Monaco and Lawrence, 2003; Werner and Grose, 2003) have been compiling the acquired knowledge on the cascade of events subsequent to tissue injury. However, the mechanisms by which organisms repair or regenerate injured tissue are not completely disclosed. Important insights have been revealed by studying the regeneration of amputated appendages of amphibians, showing that differentiated cells from mature tissues surrounding the wound dedifferentiate into mononuclear blastemal cells, which then differentiate into multiple tissue lineages (Brockes and Kumar, 2002; Suzuki et al., 2005). Also, data from developmental studies in the sponge Amphimedon queenslandica (Adamska et al., 2007) and in Drosophila melanogaster (Woolner et al., 2005) revealed remarkable 
similarity with human wound closure mechanisms, namely cell-cell interactions mediated by Wnt proteins and transforming growth factor- $\beta$ (TGF $\beta)$. Furthermore, salamanders and humans share the molecular machinery to regenerate tissues but the main difference relies on the rapid deposition of fibrotic tissue in adult humans, limiting the regenerative potential (Gurtner et al., 2008).

Human fetal skin wound healing also presents very distinct characteristics from adult healing, among which is reduced inflammatory response (Cowin et al., 1998; Ferguson and O'Kane, 2004; Hopkinson-Woolley et al., 1994). In fact, this is translated by the diminished number and persistence of inflammatory cells, such as monocytes, and by the lack of B lymphocytes (Cowin et al., 1998), until the third trimester of gestation. In fetal skin wound healing, reduction in the number and type of inflammatory and immune system cells also represents, as compared to adult process, decreased levels of inflammatory signals, cytokines and growth factors, with rapid clearance from the wound site (Table 1) (Chen et al., 2005a, 2005b; Cowin et al., 2001; Ferguson and O'Kane, 2004; Levine et al., 1993; Liechty et al., 1998, 2000a, 2000b). In addition, the difference in the inflammatory cells' presence/absence and interval of action also impact extracellular matrix formation, re-epithelialization and wound contraction (Ferguson and O'Kane, 2004). Lack of macrophages and polymorphonuclear neutrophils were shown to improve re-epithelialization and diminished scar formation (Martin et al., 2003). In fact, the presence of a more persistent acute inflammation (Adzick et al., 1985) and keratinization in adult wound healing leads to the formation of scabs, resulting in almost permanent scars (Ferguson and O'Kane, 2004). Conversely, the absence of an underlying cell growth, a sterile and relatively low moist environment, high oxygen tension (Hunt et al., 1969), slow matrix deposition and epithelialization (Lorenz et al., 1992) and extensive angiogenesis leads to a slower closure rate in adult skin healing (Ferguson and O'Kane, 2004), which might contribute to tissue regeneration.

Given the relevance of inflammatory cells and mediators within the repair/regeneration process, it is clear that the host tissue response to tissue-engineering (TE) constructs, resulting from the individual and, most importantly, the concerted action of all their elements, is of major significance in determining constructs functionality in vivo. Furthermore, the identification of major factors involved in scarless fetal wound healing, and the establishment of their corresponding role within host reaction mechanisms, might be a way to achieve tissue regeneration and functional skin tissue in particular.

\section{Host reaction}

Ideally, a TE construct aims to interact with and integrate host tissue, allowing functional re-establishment and complete recovery of the injured tissue. The resolution of inflammation, with concomitant integration of the transplant into the host tissue, precedes complete healing (Langer and Vacanti, 1993). In a TE construct, where the scaffolding material works as a temporary structure, constant change of the implanted material, due to degradation and interaction with the host environment, certainly influences the reaction from the host and, thus, tissue healing. Moreover, the presence of cells and bioactive agents in the constructs, also known as relevant players in the host reaction, raises additional concerns and further impedes understanding of their individual and concerted contributions, and consequently the achievement of ideal regeneration settings.

\subsection{Host reaction models}

Subcutaneous, intraperitoneal and intramuscular mouse and rat (Azab et al., 2007; Christenson et al., 1991; Kamath et al., 2008; Krause et al., 1993; Meinel et al., 2005; Mendez et al., 2004; Tang et al., 1998) models are the most commonly used to assess the host response to newly developed biomaterials/scaffolds for different TE applications. Despite the well-known influence of the processing methodologies the surface properties of materials (Gomes et al., 2004; Tuzlakoglu et al., 2010, 2011) and their degradation behaviour (Azab et al., 2007; Dagang et al., 2008; Gomes et al., 2008), host reaction models usually have the limitation of not dealing with the final shape of the device. Nonetheless, valuable considerations can be obtained with those models regarding acute (Azab et al., 2007; Marques et al., 2005; Rhodes et al., 2007; Spargo et al., 1994) or chronic inflammation (Azab et al., 2007; Kim et al., 2007; Marques et al., 2005; Rhodes et al., 2007), as well as long-term reactions with full integration of the biomaterials/scaffolds into the host tissue (Ishii et al., 2009; Matthews et al., 2005; Rhodes et al., 2007; Schlosser et al., 2002). Additionally, conclusions regarding the local and/or systemic effects of injectable or scaffolding materials over the host have been obtained (Azab et al., 2007; De Souza et al., 2009; Rhodes et al., 2007; Tomazic-Jezic et al., 2001). Subcutaneous and intramuscular models have mostly focused on assessing the direct effect of the biomaterial/scaffold over the implantation site. Due to muscle high degree of vascularization that assists the activation of complement and clot systems, intramuscular models can be considered more reliable for providing information on the fibrotic capsule formation and development throughout the implantation (Meinel et al., 2005; Mendez et al., 2004). Variations of classical subcutaneous implantations, such as subcutaneous air pouches (Hooper et al., 2000; Krause et al., 1993; Wooley et al., 2002), dorsal skin fold chamber (Laschke et al., 2005) or cage implants (Brodbeck et al., 2002, 2003; Kao and Lee, 2001; Marchant et al., Marchant et al. 1983, 1989; Rodriguez et al., 2008), have also demonstrated reliable results regarding the interplay between direct and indirect surface reactions of materials. Conversely, intraperitoneal models have been useful in 
Table 1. Inflammatory cells and molecules in fetal vs adult skin wound healing

\begin{tabular}{|c|c|c|c|c|}
\hline Molecule & Secreted by & Role & Fetus & Adult \\
\hline EGF & $\begin{array}{l}\text { Platelets } \\
\text { Monocytes/macrophages } \\
\text { Keratinocytes } \\
\text { Fibroblasts } \\
\text { Endothelial cells }\end{array}$ & $\begin{array}{l}\text { Re-epithelialization } \\
\text { Stimulation of } \\
\text { collagen secretion by } \\
\text { fibroblasts }\end{array}$ & - & $\begin{array}{l}\text { mRNA decreases with } \\
\text { gestational age } \\
\text { (Peled et al., 2001) }\end{array}$ \\
\hline VEGF & $\begin{array}{l}\text { Platelets } \\
\text { Mast cells } \\
\text { Neutrophils } \\
\text { Monocytes/macrophages } \\
\text { Keratinocytes } \\
\text { Fibroblasts } \\
\text { Endothelial cells }\end{array}$ & Angiogenesis & Unclear (Wilgus et al., 2008) & - \\
\hline PDGF & $\begin{array}{l}\text { Platelets } \\
\text { Mast cells } \\
\text { Monocytes/macrophages } \\
\text { Fibroblasts } \\
\text { Endothelial cells }\end{array}$ & $\begin{array}{l}\text { Fibroplasia } \\
\text { Recruitment of } \\
\text { fibroblasts to the } \\
\text { wound site }\end{array}$ & $\begin{array}{l}\text { High levels but rapid } \\
\text { clearance from } \\
\text { wound site } \\
\text { (Chen et al., 2005b) }\end{array}$ & - \\
\hline FGF & $\begin{array}{l}\text { Platelets } \\
\text { Mast cells } \\
\text { Monocytes/macrophages } \\
\text { Keratinocytes } \\
\text { Fibroblasts } \\
\text { Endothelial cells }\end{array}$ & $\begin{array}{l}\text { Matrix deposition, } \\
\text { Re-epithelialization, } \\
\text { angiogenesis, cell } \\
\text { migration } \\
\text { (endothelial, } \\
\text { keratinocyte and } \\
\text { fibroblast) }\end{array}$ & $\begin{array}{l}\text { High expression of FGF2 } \\
\text { (Chen et al., 2005b) } \\
\text { Downregulation of } \\
\text { FGF7 and FGF10 } \\
\text { (Dang et al., 2003) }\end{array}$ & - \\
\hline TGF $\beta 3$ & $\begin{array}{l}\text { Platelets } \\
\text { Mast cells } \\
\text { Neutrophils } \\
\text { Monocytes/macrophages } \\
\text { Keratinocytes } \\
\text { Fibroblasts } \\
\text { Endothelial cells }\end{array}$ & $\begin{array}{l}\text { Infiltration of PMNs } \\
\text { and } M \Phi \text {, fibroplasia, } \\
\text { matrix deposition } \\
\text { Angiogenesis }\end{array}$ & $\begin{array}{l}\text { Low levels and increased } \\
\text { clearance (Cowin et al., 2001; } \\
\text { Levine et al., 1993) }\end{array}$ & $\begin{array}{l}\text { High levels and long } \\
\text { intracellular signalling } \\
\text { (Levine et al., 1993) }\end{array}$ \\
\hline IGF-I & $\begin{array}{l}\text { Platelets } \\
\text { Monocytes/macrophages } \\
\text { Fibroblasts }\end{array}$ & $\begin{array}{l}\text { Matrix deposition } \\
\text { Scarring } \\
\text { Re-epithelialization }\end{array}$ & $\begin{array}{l}\text { Low proliferation and } \\
\text { collagen synthesis } \\
\text { (Werner and Grose, 2003) }\end{array}$ & $\begin{array}{l}\text { High proliferation and } \\
\text { collagen synthesis } \\
\text { (Rolfe et al., 2007) }\end{array}$ \\
\hline IL-1 $\beta$ & $\begin{array}{l}\text { Platelets } \\
\text { Mast cells } \\
\text { Neutrophils } \\
\text { Monocytes/macrophages } \\
\text { Keratinocytes } \\
\text { Fibroblasts } \\
\text { Endothelial cells }\end{array}$ & $\begin{array}{l}\text { Perpetuation of } \\
\text { inflammation } \\
\text { Induction of } \\
\text { proteolytic activity } \\
\text { Vascularization }\end{array}$ & $\begin{array}{l}\text { Induction of lower response } \\
\text { of fibroblasts to contraction } \\
\text { (in vitro) (Irwin et al., 1998) }\end{array}$ & $\begin{array}{l}\text { Induction of higher } \\
\text { response of fibroblasts } \\
\text { to contraction (in vitro) } \\
\text { (Irwin et al., 1998) }\end{array}$ \\
\hline IL-4 & $\begin{array}{l}\text { Platelets } \\
\text { Mast cells }\end{array}$ & $\begin{array}{l}\text { Reduction of } \\
\text { inflammation }\end{array}$ & - & $\begin{array}{l}\text { Downregulation of } \\
\text { inflammatory cytokines } \\
\text { (Leonard et al., 1993) }\end{array}$ \\
\hline IL-6 & $\begin{array}{l}\text { Mast cells } \\
\text { Monocytes/macrophages } \\
\text { Keratinocytes } \\
\text { Fibroblasts } \\
\text { Endothelial cells }\end{array}$ & $\begin{array}{l}\text { Re-epithelialization } \\
\text { and granulation tissue } \\
\text { formation }\end{array}$ & $\begin{array}{l}\text { Increased expression } \\
\text { but rapid clearance from } \\
\text { wound site (Liechty et al., } \\
2000 a^{\bullet} \text { ) }\end{array}$ & $\begin{array}{l}\text { Mitotic effect in } \\
\text { keratinocytes and } \\
\text { chemoattractive to } \\
\text { granulocytes (Sato et al., } \\
1999 \bullet^{\bullet} \text { ) }\end{array}$ \\
\hline IL-8 & $\begin{array}{l}\text { Mast cells } \\
\text { Neutrophils } \\
\text { Monocytes/macrophages } \\
\text { Keratinocytes } \\
\text { Fibroblasts } \\
\text { Endothelial cells }\end{array}$ & $\begin{array}{l}\text { Re-epithelialization } \\
\text { Inflammation } \\
\text { induction } \\
\text { Wound contraction } \\
\text { reduction }\end{array}$ & $\begin{array}{l}\text { Chemoatractant for granulocytes } \\
\text { but rapid clearance from } \\
\text { wound site (Liechty et al., } \\
\text { 1998) }\end{array}$ & $\begin{array}{l}\text { Chemoatractant for granulocytes } \\
\text { (Liechty et al., 1998; } \\
\text { Rennekampff et al., 2000) } \\
\text { Inhibition of keratinocyte } \\
\text { proliferation (Rennekampff } \\
\text { et al., 2000) }\end{array}$ \\
\hline IL-10 & $\begin{array}{l}\text { Mast cells } \\
\text { Monocytes/macrophages }\end{array}$ & $\begin{array}{l}\text { Fibrosis/scar } \\
\text { formation and } \\
\text { inflammation } \\
\text { inhibition }\end{array}$ & $\begin{array}{l}\text { Regulating the expression } \\
\text { of proinflammatory } \\
\text { cytokines (Liechty et al., } \\
2000 b^{\bullet} \text { ) }\end{array}$ & $\begin{array}{l}\text { Inhibition of granulocytes } \\
\text { and } M \Phi \text { infiltration at } \\
\text { the wound site (Sato et al., } \\
1999 \mathrm{~b}^{\bullet} \text { ) }\end{array}$ \\
\hline
\end{tabular}

evaluating the reactions of abdominal organs, such as spleen, liver, kidney, mesenteric lymph nodes and the adjacent adipose tissue (Azab et al., 2007; De Souza et al., 2009; Tomazic-Jezic et al., 2001), translating the host systemic reaction to the biomaterial/TE scaffold. Additionally, intraperitoneal and intramuscular models also allow evaluation of the systemic recruitment of host inflammatory cells and secretion of molecules after transplantation/injection at short and long time periods of reaction (Busuttil et al., 2004; Lozano et al., 2002; Tang and Eaton, 1993; Tomazic-Jezic et al., 2001; Schlosser et al., 2002). However, cell recovery from intraperitoneal fluid is easier than from intramuscular models, also allowing kinetic studies. The antigenic/immunogenic potential of a biomaterial and the consequent acquired immunity by the host has also been studied after repeated implantations in either subcutaneous or intraperitoneal rat models (Schlosser et al., 2002; van Luyn et al., 2001) . 


\subsection{Mechanistics of the host reaction to biomaterials/scaffolds}

Among inflammatory cells, macrophages, always a major player in the host reaction, recognize and react with the proteins adsorbed to the material's surface (Anderson and Miller, 1984). Although some insight has been gained regarding this surface-dependent interaction (Kao, 1999; Kao and Lee, 2001; Keselowsky et al., 2007; Schmidt and Kao, 2007), the mechanisms by which macrophages adhere and react to the different surfaces are still far from being revealed. Specific fibronectin peptide sequences, such as Pro-His-Ser-Arg-Asn (PHSRN) and Arg-Gly-Asp (RGD) were shown to elicit an early-stage foreign body giant cells (FBGCs) reaction (Kao and Lee, 2001). Thus, those domains were identified as important factors mediating macrophage adhesion to polyethyleneglycol-based surfaces and then in the formation of FBGCs (Kao and Lee, 2001). A transgenic mouse model, in which plasma fibronectin $[\mathrm{p}(\mathrm{FN})]$ was depleted (Keselowsky et al., 2007), permitted further demonstration that, besides being an important regulator of FBGCs reaction, $\mathrm{p}(\mathrm{FN})$ plays a role in fibrotic capsule formation. Additionally, two other transgenic mouse models, where either fibrinogen or plasminogen was depleted, proved that leukocyte recruitment after the intraperitoneal implantation of polyethylene terephthalate is plasminogen-dependent, while leukocyte adhesion is fibrinogen-dependent (Busuttil et al., 2004).

Ultimately, the specific cellular response to the material's surface determines the deposition of collagen by the tissuerepairing cells and consequently the extent of the fibrotic capsule deposited (Keselowsky et al., 2007). Fibrotic tissue surrounding the implant hinders the interaction of the host with the implanted biomaterial (Tang and Eaton, 1995; Wynn, 2008). This diminished interaction may protect the host from eventual material debris but, more importantly, will not allow integration of the implant into the host tissue, therefore being highly detrimental in TE approaches.

Despite the achievements using subcutaneous, intramuscular and intraperitoneal models regarding the evaluation of host inflammatory/immune reactions to biomaterials /scaffolds, understanding of the mechanisms involved on the transition from an acute to a chronic reaction, which the existing animal models are not capable of answering, is a significant lack in this field. This issue is particularly relevant for skin regeneration, due to the need to restore its integrity after injury in a short time frame. Furthermore, as the cascade of events in inflammatory/immune reactions involves crucial host cells and molecules that influence the progression of skin healing, comprehension of these insights offers important cues to lead tissue regeneration that have been poorly used or disregarded by researchers.

\subsection{Modulating the host response through modification of biomaterials}

Classically, researchers in the biomedical/TE field tend to consider the material-host interface as a key issue in evaluating tissue reactions. In fact, great efforts have been made to develop materials whose surfaces are less antigenic/immunogenic (Hetrick et al., 2007; Hickey et al., 2002; Khouw et al., 2001; Ravin et al., 2001). The reduced number and lack of in vitro models to validate the antigenic/immunogenic potential of biomaterials still renders in vivo tests more reliable for testing the success of these approaches. The effect of key molecules, such as dexamethasone (Hickey et al., 2002), nitric oxide (Hetrick et al., 2007), tumour necrosis factor- $\alpha$ (TNF $\alpha$ ), interferon- $\gamma$ (IFN $\gamma$ ) (Khouw et al., 2001), vascular endothelial growth factor (VEGF) and fibroblast growth factor- $\beta$ (FGF- $\beta$ ) (Ravin et al., 2001), has been tested in subcutaneous rat (Hetrick et al., 2007; Hickey et al., 2002) and mouse (Khouw et al., 2001) models, as well as in an intramuscular rat model (Ravin et al., 2001). However, due to given differences in the models and consequent differences in reaction mechanisms on the materials, and thus the surface properties, few remarks regarding the potential of the tested molecules in modulating the host response can be extracted.

In a TE context, these approaches easily find a parallel in the functionalization of scaffolding structures with different bioactive molecules; however, these have been mainly chosen to direct the differentiation of the transplanted cells towards a specific lineage (Altman et al., 2009; Santos et al., 2013) or to recruit progenitor cells (Aguirre et al., 2012) responsible for new tissue formation. To consider the action of those molecules as an intricate signalling network that not only directs new tissue formation but also determines the host reaction still remains to be particularly addressed.

\section{Skin healing}

The ultimate goal of skin TE is to lead the regeneration of new skin tissue with all the sensorial and aesthetic functionalities restored. Trauma and surgical procedures are the main causes of acute skin lesions and their healing mechanisms are not necessarily similar. Incisional wounds heal by primary intention (Gamelli and He, 2003), meaning that tissue loss is not extensive, the inflammatory response is not exuberant and scar formation is not a relevant issue. In contrast, skin excisions involve high tissue removal and, thus, a secondary-intention healing process (Frank and Kaempfer, 2003), characterized by abundant inflammation and granulation tissue formation, resulting in significant scarring. Acute skin wounds follow a well-established pattern of progression through the inflammatory, proliferative and maturation phases (Baum and Arpey, 2005; Fantone and Ward, 1999; Williams, 2001). It is expected that an acute excisional wound will be closed within 2 weeks, although this time frame may vary depending on the extent of the excised tissue (Monaco and Lawrence, 2003). Conversely, chronic wounds take months to years to close or might never do so. In chronic wounds, healing progression is impaired 
due to arrest at one or more stages of the process, caused by local or systemic factors. Exuberant contamination, hypoxia, trauma, presence of foreign bodies, diabetes, malnutrition, immunodeficiency and medication (Komesu et al., 2004; Robson, 1988; Williams and Harding, 2003) are among those.

\subsection{Chronic skin wound-healing models}

When an cute inflammatory reaction persists at the wound site, a chronic skin wound with delayed healing and inability to re-epithelialize within 6-8 weeks develops (Menke et al., 2007; Schultz and Wysocki, 2009). A major problem of chronic wounds with associated impaired healing relies on its different aetiologies, such as diabetes, immunosuppression, blood supply or nourishing deficiencies, glucocorticoids administration and age (Davidson, 1998; Menke et al., 2007), which do not represent a localized deficit.

Frequently, the established chronic animal models mimic delayed wound healing and not the impaired wound healing observed in the clinical condition of chronic wounds. Therefore, these models have been mainly used to try to understand the mechanisms underlying impaired healing, as the case of diabetes, in mice (Brown et al., 1997) and rats (Chen et al., 1999; Komesu et al., 2004), instead of working as proper chronic wound models for testing skin regeneration strategies. An example of an animal model that may mimic a particular characteristic of chronic wounds, such as ischaemia, is the porcine split-thickness skin wound model. Even though it is not a specific model of chronic wound formation, its impaired blood supply allows testing the potential of TE constructs to trigger angiogenesis and to promote dermal regeneration (Markowicz et al., 2006b`) ). Contrarily, rabbit (Niitsuma et al., 2003) and murine (Wassermann et al., 2009) models of decubitus ulcers, although representing a specific type of chronic wound, have been mainly used to gather further knowledge on the mechanisms of pressure ulcer development and the assessment of basic healing mechanisms of chronic wounds.

\subsection{Acute skin wound-healing models}

Incisional full-thickness wound rat (Cho et al., 1999; Hu et al., 2003; Ono et al., 2004) and mouse (Ishihara et al., 2001; Repertinger et al., 2004) models have been used to evaluate the effect of biomaterials per se, or of locally releasing growth factors over healing rates, considering skin breaking strength and bleeding cessation. However, these models are not able to offer valid information for skin TE, since healing by primary intention does not characterize the mechanisms involved in skin regeneration. In turn, partial or full-thickness excisional acute wound models are the most appropriate and the ones that were proved useful (Davidson, 1998) in predicting the biofunctionality of biomaterials for skin-related applications or of skin TE constructs. Full-thickness wound models are, contrarily to the partial-thickness models, essential to demonstrate the direct role of biomaterials (Cho et al., 1999; Choi et al., 2001; Hu et al., 2003; Ishihara et al., 2001; Noorjahan and Sastry, 2004; Sugihara et al., 2000; Suzuki et al., 1999) and TE constructs (Altman et al., 2009; Inoue et al., 2008; Markowicz et al., 2006a, 2006b•) over the healing mechanisms. Despite this, the panniculus carnosus muscle beneath the dermis is a main concern in rodents and lagomorphs models, due to tissue contraction. Moreover, the fast healing rate observed in small animals, even after the administration of steroids to impair wound healing (Saulis and Mustoe, 2001), compel researchers to adjust the rodent models, or to substitute small animals by larger animals (Ma et al., 2007; Middelkoop et al., 2004) with skin healing closer to humans. The resemblances between human and porcine skin (Metcalfe and Ferguson, 2007) support the reliability of these models. In fact, swine fullthickness skin excisional models have proved useful and reliable tools to evaluate skin regeneration after the grafting of skin tissue-engineering constructs. In fact, results concerning the involvement of transplanted cells (mostly autologous keratinocytes), acellular matrices and host cells and molecules (Butler and Orgill, 2005; Druecke et al., 2004; Jones et al., 2003; Melendez et al., 2008; Wood et al., 2007) obtained with this model were translated to the clinic. Therefore, these and the similarities between porcine and human skin healing counterbalances the high costs and demanding logistics of using this model, and support controversy about the relevance of the results obtained with the different acute skin wound healing rodent models.

Researchers are not prone to using comparative animal models to evaluate the functionality of the proposed approaches. Either the constructs are only tested in rodents or directly transplanted into porcine models. From our perspective, these models could complement each other. The possibility of directly comparing the healing microenvironment evaluated in skin-healing models with the reaction to the scaffolding material determined in host-response models could somehow surpass the limitation of the rodent models. Thus, a systematization of this comparative approach would contribute to better predicting the functionality of the constructs and refine the TE strategies to be tested in larger animal models afterwards.

\section{Host reaction vs skin regeneration}

Inflammation and wound healing share the extraordinarily important feature of restoring the homeostatic status of a living body. Inevitably, wound healing is preceded by inflammation; the key inflammatory cells and mediators also share functions in the progression of wound healing and tissue regeneration, especially in skin. Polymorphonuclear neutrophils (PMNs), macrophages 
$(\mathrm{M} \Phi)$, mast cells, lymphocytes and platelets secrete a wide range of molecules that balance the inflammatory response, but are also involved in the stimulation or restraint of matrix deposition, cell infiltration, vascularization, angiogenesis and re-epithelialization during skin healing. A clear crosstalk between the inflammatory and connective tissue cells (e.g. fibroblasts) that, in a first stage, regulate the resolution of inflammation and then the restoration of the original tissue, demonstrates the existing interplay. After 6 weeks of implantation in fullthickness porcine wounds, mononuclear cells ( $M \Phi$ s and lymphocytes) and giant cells were found in direct contact with the collagen scaffold fibres of Integra. Although no signs of phagocytosis were observed, the number of giant cells was significantly higher than in healthy tissue (Druecke et al., 2004; Melendez et al., 2008). This decodes an activation of $M \Phi$ s, inducing them to fuse without achieving the phagocytosis step. In a subsequent study, (Agrawal et al., 2012) identified the presence of M1 and M2 type $M \Phi$ s up to 42 days postimplantation of Integra $(\mathrm{R})$, associated with a more constructive tissue remodelling response than for AlloDerm ${ }^{\circledR}$. In this case, $M \Phi$ s were predominantly M1 and a more inflammatory-type tissue remodelling outcome was observed. Thus, a balanced effect where, due to the persistent presence of the Integra (R) scaffold, M1 type M $\Phi$ s influenced the formation of giant cells and the M2 M $\Phi$ s led skin healing towards a fibrosis-free scar was potentially occurring. Thus, in the context of biomaterials, the host response and the progression to a wound-healing profile, the cytokines produced by the M2 polarized macrophages, known to have anti-inflammatory potential, are expected to aid tissue remodelling and vascularization and to inhibit fibrous tissue formation (Gordon and Martinez, 2010). The capacity of a biomaterial to modulate the expression of inflammatory mediators and the time course of cutaneous healing, particularly the relationship between IL-8 expression and re-epithelialization, was also demonstrated (Kleinbeck et al., 2010). Thus, an intervention in the early stage of wound healing, particularly targeting the inflammatory mediators, is expected to trigger the skin tissue regeneration pathway, providing better outcomes than the current strategies, which have been mainly targeting the later phases of proliferation and remodelling.
The improvement of scarless skin healing was also associated with beneficial crosstalk between the transplanted keratinocytes and host fibroblasts (Melendez et al., 2008). In fact, autologous keratinocytes in combination with Integra (R) were shown to enhance the epithelialization of porcine full-thickness wounds (Jones et al., 2003; Melendez et al., 2008; Wood et al., 2007) and seemed to influence the progression of the inflammatory reaction towards a more remodelling-prone response.

Overall, it seems evident that, by identifying and studying the cells and molecules involved in the ongoing resolution of the host reaction to skin TE constructs, important insights could be drawn in the context of restoring homeostasis with skin tissue regeneration.

\section{Final Remarks}

From this overview, it becomes clear that inflammatory and immune cells, as well as the associated mediators (cytokines and growth factors) involved in the host reaction to material/TE scaffolds, are intrinsically related to the progression of skin tissue healing into scar formation (repair) or regeneration. Although demonstration is yet to be attained, it is likely that a material that elicits a less severe inflammatory response is more prone to trigger skin regeneration rather than repair. Nonetheless, the interplay and complexity of these phenomena significantly hinder the controlled and well-designed approaches that have yet to be proposed. Exploitation of the knowledge acquired from host tissue reaction models to predict and modulate skin tissue healing is seen as an extremely valuable approach to attain this. Ultimately, this complementarity will benefit the development of improved skin TE constructs capable of modulating the progression of the host reaction by targeting the key signalling pathways that rule skin regeneration.

\section{Acknowledgements}

T.C.S. acknowledges Grant No. RL3-TECT-NORTE-01-0124FEDER-000020, co-financed by the North Portugal Regional Operational Programme (ON.2-O Novo Norte), under the National Strategic Reference Framework, through the European Regional Development Fund.

\section{References}

Adamska M, Degnan SM, Green KM, et al. 2007; Wnt and TGF $\beta$ expression in the sponge Amphimedon queenslandica and the origin of metazoan embryonic patterning. PLoS One 2: 1-6.

Adzick NS, Harrison MR, Glick PL, et al. 1985; Comparison of fetal, newborn, and adult wound healing by histologic, enzyme-histochemical, and hydroxyproline determinations. J Pediatr Surg 20: 315-319.
Agrawal H, Tholpady SS, Capito AE, et al. 2012; Macrophage phenotypes correspond with remodeling outcomes of various acellular dermal matrices. Open J Regen Med 1: 51-59.

Aguirre A, Gonzalez A, Navarro M, et al. 2012; Control of microenvironmental cues with a smart biomaterial composite promotes endothelial progenitor cell angiogenesis. Eur Cells Mater 24: 90-106.
Altman AM, Yan Y, Matthias N, et al. 2009; IFATS collection: human adipose-derived stem cells seeded on a silk fibroin-chitosan scaffold enhance wound repair in a murine soft tissue injury model. Stem Cells 27: 250-258.

Anderson JM, Miller KM 1984; Biomaterial biocompatibility and the macrophage. Biomaterials 5: 5-10.

Azab AK, Doviner V, Orkin B, et al. 2007; Biocompatibility evaluation of crosslinked 
chitosan hydrogels after subcutaneous and intraperitoneal implantation in the rat. J Biomed Mater Res A 83: 414-422.

Baum CL, Arpey CJ 2005; Normal cutaneous wound healing: clinical correlation with cellular and molecular events. Dermatol Surg 31: 674-686.

Brockes JP, Kumar A 2002; Plasticity and reprogramming of differentiated cells in amphibian regeneration. Nat Rev $\mathrm{Mol}$ Cell Biol 3: 566-574.

Brodbeck WG, Patel J, Voskerician G, et al. 2002; Biomaterial adherent macrophage apoptosis is increased by hydrophilic and anionic substrates in vivo. Proc Natl Acad Sci USA 99: 10287-10292.

Brodbeck WG, Voskerician G, Ziats NP, et al. 2003; In vivo leukocyte cytokine mRNA responses to biomaterials are dependent on surface chemistry. $J$ Biomed Mater Res A 64: 320-329.

Brown DL, Kao WW, Greenhalgh DG 1997; Apoptosis downregulates inflammation under the advancing epithelial wound edge: delayed patterns in diabetes and improvement with topical growth factors. Surgery 121: 372-380.

Busuttil SJ, Ploplis VA, Castellino FJ, et al. 2004; A central role for plasminogen in the inflammatory response to biomaterials. J Thromb Haemost 2: 1798-1805

Butler CE, Orgill DP 2005; Simultaneous in vivo regeneration of neodermis, epidermis, and basement membrane. Adv Biochem Eng Biotechnol 94: 23-41.

Chen C, Schultz GS, Bloch M, et al. 1999; Molecular and mechanistic validation of delayed healing rat wounds as a model for human chronic wounds. Wound Repair Regen 7: 486-494.

Chen W, Fu X, Ge S, et al. 2005a; Ontogeny of expression of transforming growth factor- $\beta$ and its receptors and their possible relationship with scarless healing in human fetal skin. Wound Repair Regen 13: 68-75.

Chen W, Fu XB, Ge SL, et al. 2005b; Ontogeny of expression of basic fibroblast growth factor and its receptors in human fetal skin. Chin J Traumatol 8: 332-338.

Cho YW, Cho YN, Chung SH, et al. 1999; Water-soluble chitin as a wound healing accelerator. Biomaterials 20: 2139-2145.

Choi YS, Lee SB, Hong SR, et al. 2001; Studies on gelatin-based sponges. Part III: A comparative study of cross-linked gelatin/alginate, gelatin/hyaluronate and chitosan/hyaluronate sponges and their application as a wound dressing in fullthickness skin defect of rat. $J$ Mater Sci Mater Med 12: 67-73.

Christenson L, Wahlberg L, Aebischer P 1991; Mast cells and tissue reaction to intraperitoneally implanted polymer capsules. $J$ Biomed Mater Res 25: 1119-1131.

Cowin AJ, Brosnan MP, Holmes TM, et al. 1998; Endogenous inflammatory response to dermal wound healing in the fetal and adult mouse. Dev Dyn 212: 385-393.

Cowin AJ, Holmes TM, Brosnan P, et al. 2001; Expression of TGF $\beta$ and its receptors in murine fetal and adult dermal wounds. Eur J Dermatol 11: 424-431.

Dagang G, Kewei X, Yong H 2008; The influence of $\mathrm{Sr}$ doses on the in vitro biocompatibility and in vivo degradability of single-phase Sr-incorporated HAP cement. J Biomed Mater Res A 86: 947-958.
Dang CM, Beanes SR, Soo C, et al. 2003; Decreased expression of fibroblast and keratinocyte growth factor isoforms and receptors during scarless repair. Plast Reconstr Surg 111: 1969-1979.

Davidson JM 1998; Animal models for wound repair. Arch Dermatol Res 290 (suppl): S1-S11.

De Souza R, Zahedi P, Allen CJ, et al. 2009; Biocompatibility of injectable chitosanphospholipid implant systems. Biomaterials 30: 3818-3824.

Druecke D, Lamme EN, Hermann S, et al. 2004: Modulation of scar tissue formation using different dermal regeneration templates in the treatment of experimenta full-thickness wounds. Wound Repair Regen 12: 518-527.

Fantone J, Ward P 1999; Inflammation. In Pathology, E R, J F (eds). LippincottRaven: Philadelphia: 36-75.

Ferguson MW, O'kane S 2004; Scar-free healing: from embryonic mechanisms to adult therapeutic intervention. Phil Trans $R$ Soc Lond B Biol Sci 359: 839-850.

Frank S, Kaempfer H 2003; Excisional wound healing: an experimental approach. In Wound Healing: Methods and Protocols, La DP, Al B (eds). Humana: Totowa, NJ: $3-15$.

Gamelli RL, He LK 2003; Incisional wound healing: model and analysis of wound breaking strength. In Wound Healing: Methods and Protocols, La DP, Al B (eds). 37-54Humana: Totowa, NJ.

Gomes ME, Azevedo HS, Moreira AR, et al. 2008; Starch-poly( $\varepsilon$-caprolactone) and starch-poly(lactic acid) fibre-mesh scaffolds for bone tissue engineering applications: structure, mechanical properties and degradation behaviour. $J$ Tissue Eng Regen Med 2: 243-252.

Gomes ME, Malafaya PB, Reis RL 2004; Methodologies for processing biodegradable and natural origin scaffolds for bone and cartilage tissue-engineering applications. Methods Mol Biol 238: 65-76.

Gordon S, Martinez FO 2010; Alternative activation of macrophages: mechanism and functions. Immunity 32: 593-604.

Gurtner GC, Werner S, Barrandon Y, et al 2008; Wound repair and regeneration. Nature 453: 314-321.

Hetrick EM, Prichard HL, Klitzman B, et al. 2007; Reduced foreign body response at nitric oxide-releasing subcutaneous implants. Biomaterials 28: 4571-4580.

Hickey T, Kreutzer D, Burgess DJ, et al. 2002; In vivo evaluation of a dexamethasone/PLGA microsphere system designed to suppress the inflammatory tissue response to implantable medical devices. $J$ Biomed Mater Res 61 : 180-187.

Hooper KA, Nickolas TL, Yurkow EJ, et al. 2000; Characterization of the inflammatory response to biomaterials using a rodent air pouch model. $J$ Biomed Mater Res 50: 365-374.

Hopkinson-Woolley J, Hughes D, Gordon S, et al. 1994; Macrophage recruitment during limb development and wound healing in the embryonic and fetal mouse. $J$ Cell Sci 107: 1159-1167.

Hu M, Sabelman EE, Cao Y, et al. 2003; Three-dimensional hyaluronic acid grafts promote healing and reduce scar formation in skin incision wounds. $J$ Biomed $M a$ ter Res B Appl Biomater 67: 586-592.
Hunt TK, Zederfeldt B, Goldstick TK 1969 Oxygen and healing. Am J Surg 118: 521-525.

Inoue H, Murakami T, Ajiki T, et al. 2008 Bioimaging assessment and effect of skin wound healing using bone-marrowderived mesenchymal stromal cells with the artificial dermis in diabetic rats. $J$ Biomed Opt 13: 064036.

Irwin CR, Myrillas T, Smyth M, et al. 1998; Regulation of fibroblast-induced collagen gel contraction by interleukin-1 $\beta$. J Oral Pathol Med 27: 255-259.

Ishihara M, Ono K, Sato M, et al. 2001; Acceleration of wound contraction and healing with a photocrosslinkable chitosan hydrogel. Wound Repair Regen 9: 513-521.

Ishii D, Ying TH, Mahara A, et al. 2009; In vivo tissue response and degradation behavior of PLLA and stereocomplexed PLA nanofibers. Biomacromolecules $\mathbf{1 0}$ 237-242.

Jones I, James SE, Rubin P, et al. 2003; Upward migration of cultured autologous keratinocytes in Integra artificial skin: a preliminary report. Wound Repair Regen 11: 132-138.

Kamath S, Bhattacharyya D, Padukudru C et al. 2008; Surface chemistry influences implant-mediated host tissue responses. $J$ Biomed Mater Res A 86: 617-626.

Kao WJ 1999; Evaluation of proteinmodulated macrophage behavior on biomaterials: designing biomimetic materials for cellular engineering. Biomaterials 20: 2213-2221.

Kao WJ, Lee D 2001; In vivo modulation of host response and macrophage behavior by polymer networks grafted with fibronectin-derived biomimetic oligopeptides: the role of RGD and PHSRN domains. Biomaterials 22: 2901-2909.

Keselowsky BG, Bridges AW, Burns KL, et al. 2007; Role of plasma fibronectin in the foreign body response to biomaterials. Biomaterials 28: 3626-3631.

Khouw IM, van Wachem PB, Plantinga JA, et al. 2001; Enzyme and cytokine effects on the impaired onset of the murine foreign-body reaction to dermal sheep collagen. J Biomed Mater Res 54: 234-240.

Kim MS, Ahn HH, Chin YN, et al. 2007; An in vivo study of the host tissue response to subcutaneous implantation of PLGA- and/or porcine small intestinal submucosa-based scaffolds. Biomaterials 28: 5137-5143.

Kleinbeck KR, Faucher LD, Kao WJ 2010; Biomaterials modulate interleukin- 8 and other inflammatory proteins during reepithelialization in cutaneous partialthickness wounds in pigs. Wound Repair Regen 18: 486-498.

Komesu MC, Tanga MB, Buttros KR, et al. 2004; Effects of acute diabetes on rat cutaneous wound healing. Pathophysiology 11: 63-67.

Krause TJ, Robertson FM, Greco RS 1993; Measurement of intracellular hydrogen peroxide induced by biomaterials implanted in a rodent air pouch. $J$ Biomed Mater Res 27: 65-69.

Langer R, Vacanti JP 1993; Tissue engineering. Science 260: 920-926.

Laschke MW, Haufel JM, Thorlacius H, et al. 2005; New experimental approach to study host tissue response to surgical mesh materials in vivo. $J$ Biomed Mater Res A 74: 696-704. 
Leonard EJ, Skeel A, Yoshimura T, et al. 1993; Secretion of monocyte chemoattractant protein-1 (MCP-1) by human mononuclear phagocytes. Adv Exp Med Biol 351: 55-64.

Levine JH, Moses HL, Gold LI, et al. 1993; Spatial and temporal patterns of immunoreactive transforming growth factors $\beta 1$, $\beta 2$ and $\beta 3$ during excisional wound repair. Am J Pathol 143: 368-380.

Liechty KW, Adzick NS, Crombleholme TM 2000a; Diminished interleukin 6 (IL-6) production during scarless human fetal wound repair. Cytokine 12: 671-676

Liechty KW, Crombleholme TM, Cass DL, et al. 1998; Diminished interleukin-8 (IL-8) production in the fetal wound healing response. $J$ Surg Res 77: 80-84.

Liechty KW, Kim HB, Adzick NS, et al. 2000b; Fetal wound repair results in scar formation in interleukin-10-deficient mice in a syngeneic murine model of scarless fetal wound repair. J Pediatr Surg 35: 866-872.

Lorenz HP, Longaker MT, Perkocha LA, et al. 1992; Scarless wound repair: a human fetal skin model. Development 114: 253-259.

Lozano FS, Garcia-Criado FJ, Fresnadillo MJ, et al. 2002; Systemic inflammatory response induced by Dacron graft and modulation by antimicrobial agents: experimental study. J Surg Res 107: 7-13.

Ma L, Shi Y, Chen Y, et al. 2007; In vitro and in vivo biological performance of collagenchitosan/silicone membrane bilayer dermal equivalent. J Mater Sci Mater Med 18: 2185-2191.

Marchant R, Hiltner A, Hamlin C, et al. 1983; In vivo biocompatibility studies. I. The cage implant system and a biodegradable hydrogel. J Biomed Mater Res 17: 301-325.

Marchant RE 1989; The cage implant system for determining in vivo biocompatibility of medical device materials. Fundament Appl Toxicol 13: 217-227.

Markowicz M, Koellensperger E, Neuss S, et al. 2006a; Human bone marrow mesenchymal stem cells seeded on modified collagen improved dermal regeneration in vivo. Cell Transpl 15: 723-732.

Markowicz MP, Steffens GCM, Fuchs PC et al. 2006b; Enhanced dermal regeneration using modified collagen scaffolds: experimental porcine study. Int $J$ Artif Organs 29: 1167-1173.

Marques AP, Reis RL, Hunt JA 2005; An in vivo study of the host response to starch-based polymers and composites subcutaneously implanted in rats. Macromol Biosci 5: 775-785.

Martin P, D'souza D, Martin J, et al. 2003; Wound healing in the PU.1-null mouse tissue repair is not dependent on inflammatory cells. Curr Biol 13: 1122-1128.

Martin P, Leibovich SJ 2005; Inflammatory cells during wound repair: the good, the bad and the ugly. Trends Cell Biol 15: 599-607.

Matthews BD, Mostafa G, Carbonell AM, et al. 2005; Evaluation of adhesion formation and host tissue response to intraabdominal polytetrafluoroethylene mesh and composite prosthetic mesh. J Surg Res 123: 227-234.

Meinel L, Hofmann S, Karageorgiou V, et al. 2005; The inflammatory responses to silk films in vitro and in vivo. Biomaterials 26: 147-155.
Melendez MM, Martinez RR, Dagum AB, et al. 2008; Porcine wound healing in fullthickness skin defects using Integra with and without fibrin glue with keratinocytes. Can J Plastic Surg 16: 147-152.

Mendez JA, Fernandez M, Gonzalez-Corchon A, et al. 2004; Injectable self-curing bioactive acrylic-glass composites charged with specific anti-inflammatory/analgesic agent. Biomaterials 25: 2381-2392.

Menke NB, Ward KR, Witten TM, et al. 2007; Impaired wound healing. Clin Dermato 25: 19-25.

Metcalfe AD, Ferguson MW 2007; Tissue engineering of replacement skin: the crossroads of biomaterials, wound healing, embryonic development, stem cells and regeneration. $J$ Roy Soc Interface 4: 413-437.

Middelkoop E, van den Bogaerdt AJ, Lamme EN, et al. 2004; Porcine wound models for skin substitution and burn treatment. Biomaterials 25: 1559-1567.

Monaco JL, Lawrence WT 2003; Acute wound healing an overview. Clin Plast Surg 30: 1-12.

Niitsuma J, Yano H, Togawa T 2003; Experimental study of decubitus ulcer formation in the rabbit ear lobe. $J$ Rehabil Res Dev 40: 67-73.

Noorjahan SE, Sastry TP 2004; An in vivo study of hydrogels based on physiologically clotted fibrin-gelatin composites as wound-dressing materials. J Biomed Mater Res B Appl Biomater 71: 305-312.

Ono I, Yamashita T, Hida T, et al. 2004; Local administration of hepatocyte growth factor gene enhances the regeneration of dermis in acute incisional wounds. $J$ Surg Res 120: $47-55$

Peled ZM, Rhee SJ, Hsu M, et al. 2001; The ontogeny of scarless healing II: EGF and $P D G F-B$ gene expression in fetal rat skin and fibroblasts as a function of gestational age. Ann Plast Surg 47: 417-424.

Ravin AG, Olbrich KC, Levin LS, et al. 2001; Long- and short-term effects of biological hydrogels on capsule microvascular density around implants in rats. $J$ Biomed Mater Res 58: 313-318.

Rennekampff HO, Hansbrough JF, Kiessig V, et al. 2000; Bioactive interleukin-8 is expressed in wounds and enhances wound healing. J Surg Res 93: 41-54.

Repertinger SK, Campagnaro E, Fuhrman J, et al. 2004; EGFR enhances early healing after cutaneous incisional wounding. $J$ Invest Dermatol 123: 982-989.

Rhodes NP, Bartolo CD, Hunt JA 2007; Analysis of the cellular infiltration of benzylesterified hyaluronan sponges implanted in rats. Biomacromolecules 8: 2733-2738.

Robson MC 1988; Burn sepsis. Crit Care Clin 4: 281-298.

Rodriguez A, Voskerician G, Meyerson H, et al. 2008; T cell subset distributions following primary and secondary implantation at subcutaneous biomaterial implant sites. J Biomed Mater Res A 85: 556-565.

Rolfe KJ, Cambrey AD, Richardson J, et al. 2007; Dermal fibroblasts derived from fetal and postnatal humans exhibit distinct responses to insulin like growth factors. BMC Dev Biol 7: 124

Santos TC, Morton T, Moritz M, et al. 2013 VEGF and FGF-2 incorporation in starchbased bone tissue engineering constructs promote the in vivo expression of neovascularization mediators. Tissue Eng A 19: 834-848.

Sato M, Sawamura D, Ina S, et al. 1999a; In vivo introduction of the interleukin 6 gene into human keratinocytes: induction of epidermal proliferation by the fully spliced form of interleukin 6 , but not by the alternatively spliced form. Arch Dermatol Res 291: 400-404.

Sato Y, Ohshima T, Kondo T 1999b; Regulatory role of endogenous interleukin-10 in cutaneous inflammatory response of murine wound healing. Biochem Biophys Res Commun 265: 194-199.

Saulis A, Mustoe TA 2001; Models of wound healing in growth factor studies. In Surgery Research, Ww S, Dw W (eds). Academic Press: New York: 857-874.

Schlosser M, Wilhelm L, Urban G, et al. 2002; Immunogenicity of polymeric implants: long-term antibody response against polyester (Dacron) following the implantation of vascular prostheses into LEW.1A rats. $J$ Biomed Mater Res 61: 450-457.

Schmidt DR, Kao WJ 2007; The interrelated role of fibronectin and interleukin-1 in biomaterial-modulated macrophage function. Biomaterials 28: 371-382.

Schultz GS, Wysocki A 2009; Interactions between extracellular matrix and growth factors in wound healing. Wound Repair Regen 17: 153-162.

Spargo BJ, Rudolph AS, Rollwagen FM 1994; Recruitment of tissue resident cells to hydrogel composites: in vivo response to implant materials. Biomaterials 15: 853-858. Sugihara A, Sugiura K, Morita H, et al. 2000; Promotive effects of a silk film on epidermal recovery from full-thickness skin wounds. Proc Soc Exp Biol Med 225: 58-64.

Suzuki M, Satoh A, Ide H, et al. 2005; Nervedependent and -independent events in blastema formation during Xenopus froglet limb regeneration. Dev Biol 286: 361-375. Suzuki Y, Tanihara M, Nishimura Y, et al. 1999; In vivo evaluation of a novel alginate dressing. J Biomed Mater Res 48: 522-527.

Tang L, Eaton JW 1993; Fibrin(ogen) mediates acute inflammatory responses to biomaterials. $J$ Exp Med 178: 2147-2156.

Tang L, Eaton JW 1995; Inflammatory responses to biomaterials. Am J Clin Pathol 103: 466-4671.

Tang L, Jennings TA, Eaton JW 1998; Mast cells mediate acute inflammatory responses to implanted biomaterials. Proc Natl Acad Sci USA 95: 8841-8846.

Tomazic-Jezic VJ, Merritt K, Umbreit TH 2001; Significance of the type and the size of biomaterial particles on phagocytosis and tissue distribution. $J$ Biomed Mater Res 55: 523-529.

Tuzlakoglu K, Pashkuleva I, Rodrigues MT, et al. 2010; A new route to produce starch-based fiber mesh scaffolds by wet spinning and subsequent surface modification as a way to improve cell attachment and proliferation. $J$ Biomed Mater Res A 92: 369-377.

Tuzlakoglu K, Santos MI, Neves N, et al. 2011; Design of nano- and microfiber combined scaffolds by electrospinning of collagen onto starch-based fiber meshes: a man-made equivalent of natural extracellular matrix. Tissue Eng A 17: 463-473.

van Luyn MJ, Plantinga JA, Brouwer LA, et al. 2001; Repetitive subcutaneous 
implantation of different types of (biodegradable) biomaterials alters the foreign body reaction. Biomaterials 22: 1385-1391.

Wassermann E, van Griensven M, Gstaltner $\mathrm{K}$, et al. 2009; A chronic pressure ulcer model in the nude mouse. Wound Repair Regen 17: 480-484.

Werner S, Grose R 2003; Regulation of wound healing by growth factors and cytokines. Physiol Rev 83: 835-870.

Wilgus TA, Ferreira AM, Oberyszyn TM, et al. 2008; Regulation of scar formation by vascular endothelial growth factor. $L a b I n-$ vest 88: $579-590$.

Williams DF 2001; Biocompatibility principles. In Encyclopedia of Materials: Science and Technology, Elsevier Science: Amsterdam: 542-548.

Williams DT, Harding K 2003; Healing responses of skin and muscle in critical illness. Crit Care Med 31: S547-S557.

Wood FM, Stoner ML, Fowler BV, et al. 2007; The use of a non-cultured autologous cell suspension and Integra dermal regeneration template to repair full-thickness skin wounds in a porcine model: a one-step process. Burns 33: 693-700.

Wooley PH, Morren R, Andary J, et al. 2002; Inflammatory responses to orthopaedic biomaterials in the murine air pouch. Biomaterials 23: 517-526.

Woolner S, Jacinto A, Martin P 2005; The small GTPase Rac plays multiple roles in epithelial sheet fusion - dynamic studies of Drosophila dorsal closure. Dev Biol 282: 163-173.

Wynn TA 2008; Cellular and molecular mechanisms of fibrosis. $J$ Pathol 214: 199-210. 